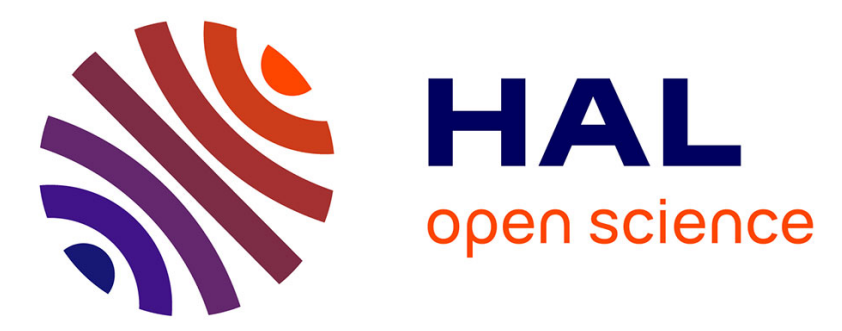

\title{
Cell free Microcystis aeruginosa spent medium affects Daphnia magna survival and stress response
}

Gorenka Bojadzija Savic, H Colinet, Myriam Bormans, Christine Edwards, Linda Lawton, Enora Briand, Claudia Wiegand

\section{- To cite this version:}

Gorenka Bojadzija Savic, H Colinet, Myriam Bormans, Christine Edwards, Linda Lawton, et al.. Cell free Microcystis aeruginosa spent medium affects Daphnia magna survival and stress response. Toxicon, 2021, 195, pp.37-47. 10.1016/j.toxicon.2021.03.009 . hal-03172862

HAL Id: hal-03172862

\section{https://hal-univ-rennes1.archives-ouvertes.fr/hal-03172862}

Submitted on 18 May 2021

HAL is a multi-disciplinary open access archive for the deposit and dissemination of scientific research documents, whether they are published or not. The documents may come from teaching and research institutions in France or abroad, or from public or private research centers.
L'archive ouverte pluridisciplinaire HAL, est destinée au dépôt et à la diffusion de documents scientifiques de niveau recherche, publiés ou non, émanant des établissements d'enseignement et de recherche français ou étrangers, des laboratoires publics ou privés. 


\section{Cell free Microcystis aeruginosa spent medium affects}

3 Daphnia magna survival and stress response

4 Gorenka Bojadzija Savic ${ }^{1 *}$, Hervé Colinet ${ }^{1}$, Myriam Bormans ${ }^{1}$, Christine Edwards ${ }^{2}$, Linda

5 A. Lawton ${ }^{2}$, Enora Briand ${ }^{3}$, Claudia Wiegand ${ }^{1}$

${ }^{1}$ UMR ECOBIO 6553 CNRS, Université de Rennes 1, Campus de Beaulieu, Rennes, France

${ }^{2}$ School of Pharmacy and Life Sciences, Robert Gordon University, Aberdeen, United Kingdom, AB10 7GJ.

${ }^{3}$ IFREMER, Phycotoxins Laboratory, F-44311 Nantes, France.

*Corresponding author: gorenka.bojadzija@gmail.com

Abstract: Primary consumers in freshwater ecosystems, such as the zooplankton organism Daphnia magna, are highly affected by cyanobacteria, both as they may use it as a food source but also by cyanobacterial metabolites present in the water. Here, we investigate the impacts of cyanobacterial metabolites focussing on the environmental realistic scenario of the naturally released mixture without crushing cyanobacterial cells or their uptake as food. Therefore, D. magna were exposed to two concentrations of cell free cyanobacterial spent medium from Microcystis aeruginosa PCC 7806 to represent higher and lower ecologicallyrelevant concentrations of cyanobacterial metabolites. Including microcystin-LR, 11 metabolites have been detected of which 5 were quantified. Hypothesising concentration and time dependent negative impact, survival, gene expression marking digestion and metabolism, oxidative stress response, cell cycle and molting as well as activities of detoxification and antioxidant enzymes were followed for 7 days. D. magna suffered from oxidative stress as both catalase and glutathione $S$-transferase enzyme activities significantly decreased, suggesting enzyme exhaustibility after 3 and 7 days. Moreover, gene-expressions of the 4 stress markers (glutathione S-transferase, glutathione peroxidase, catalase and thioredoxin) were merely downregulated after 7 days of exposure. Energy allocation (expression of Glyceraldehyde-3-phosphate dehydrogenase) was increased after 3 days but decreased as well after 7 days exposure. Cell cycle was impacted time dependently but differently by the two concentrations, along with an increasing downregulation of myosin heavy chain responsible for cell arrangement and muscular movements. Deregulation of nuclear hormone receptor genes indicate that $D$. magna hormonal steering including molting seemed impaired despite no detection of microviridin $\mathrm{J}$ in the extracts. As a consequence of all those responses and presumably of more than investigated molecular and physiological changes, D. magna survival was impaired over time, in a concentration dependent manner. Our results confirm that besides microcystin-LR, other secondary metabolites contribute to negative impact on D. magna survival and stress response.

Keywords: zooplankton; cyanobacteria; secondary metabolites; PCC7806; oxidative stress; transcriptomics

\section{Abbreviations}


MC-LR: microcystin-LR

AC: aerucyclamide

CP-A: cyanopeptolin A

LC: cyanobacterial spent medium diluted with the BG11 in the ratio 1:400

HC: cyanobacterial spent medium diluted with the BG11 in the ratio 1:40

\section{Acknowledgements}

We are grateful to D. Azam and M. Coke from the PEARL INRA 1036 U3E system (The

National Infrastructure in Biology and Health, France) for providing the Daphnia magna strain (originating from l'INERIS) and Bertrand Le Rouzic (University of Rennes 1) for providing us with the Scenedesmus communis culture (originating from the lake of Grand Lieu). We are thankful to Sophie Michon-Coudouel and Virginie Daburon who performed genetic analyses at the molecular ecology platform (UMR 6553 Ecobio, Rennes, CNRS/UR1), as well as Marion Chorin from Plateforme EcoChimie (EcoChim, UMS OSUR 3343) for help with enzyme analysis. We would like to thank Len Montgomery (Robert Gordon University) for proofreading the manuscript.

65

\section{Funding}

Gorenka Bojadzija Savic was supported by a Presidential scholarship from the University of Rennes 1. The project benefited from funding from the Centre National de la Recherche Scientifique (CNRS) Initiative Structurante Ecosphère continentale et côtière (EC2CO) under the Interactions métaboliques entre cyanobactéries et daphnies (MICYDA) project. Gorenka Bojadzija Savic was granted a mobility grant from the Doctoral School EGAAL (Bretagne-Loire, France) to visit the Robert Gordon University in Aberdeen, Scotland for metabolites analyses.

\section{Declaration of interests}

$\bigotimes$ The authors declare that they have no known competing financial interests or personal 
Due to eutrophication in freshwater ecosystems, cyanobacterial proliferation frequently results in blooms that potentially produce bioactive or toxic metabolites that harm the environment and humans (Heisler et al., 2008). Microcystis is one of the most widespread cyanobacterial genus in freshwaters, with Microcystis aeruginosa being one of the most commonly detected and investigated (Svirčev et al., 2019). Like other cyanobacteria, Microcystis produces a diverse range of secondary metabolites that have been shown to impact life traits and physiology of aquatic organisms including zooplankton such as Daphnia (Lürling and van der Grinten, 2003; Merwe and Sebbag, 2012). One of the most detected toxins produced by cyanobacteria is microcystin (MC), with more than 250 variants described so far (Mowe et al., 2015; Svirčev et al., 2019). Microcystins change the phosphorylation state of proteins by inhibiting 1 and 2A protein phosphatases, thus disrupting pathways involving phosphorylation (MacKintosh et al., 1990; Trinkle-Mulcahy and Lamond, 2006; Zurawell et al., 2005). Furthermore, microcystins trigger oxidative stress in aquatic organisms (Amado and Monserrat, 2010).

Besides microcystins, Microcystis sp. produces a wide range of intracellular and extracellular secondary metabolites such as aeruginosins, cyanopeptolins, cyclamides, microginins and microviridins (Welker and Von Döhren, 2006), that have various negative effects on Daphnia physiology (Rohrlack et al. 2001, Bister et al. 2004, Ishida et al. 2007, von Elert et al. 2012). Similar to microcystins, cyanopeptolins (CP) are synthesized through non-ribosomal metabolic pathways, by non-ribosomal peptide synthetases (NRPSs) and polyketide synthase (PKS) (Welker and Von Döhren, 2006). CP are widely distributed and diverse compounds with more than 82 variants described so far (Gademann et al. 2010). Aeruginosins are synthesized non-ribosomally and they can inhibit trypsin-type serine proteases (Ishida et al. 2000, 2007). CPs and aeruginosins are potent inhibitors of the serine proteases trypsin and chymotrypsin, that are among the main digestive enzymes in Daphnia (von Elert et al. 2005; Gademann and Portmann 2008; Elkobi-Peer et al. 2013). Microviridins are one of the largest oligopeptides produced in cyanobacteria, with 13 to 14 amino acids (1600-1900 Da), contrasting to the other groups, they are ribosomally synthesized tricyclic depsipeptides. They are produced by different cyanobacterial genera, including Microcystis sp., however, the natural 
114 diversity of microviridins is still unknown (Gatte-Picchi et al., 2014; Ziemert et al., 2010).

115 Microviridin $\mathrm{J}$ has been identified as causing fatal molting disruption in Daphnia pulicaria

116 via inhibition of Daphnia proteases, thus leading to the death of the animals (Kaebernick et

117 al., 2001; Rohrlack et al., 2004). Cyclamides are cyclic hexapeptides with cytotoxic

118 properties to crustacea (Ishida et al., 2000; Portmann et al., 2008). Cyanopeptides can occur

119 in high frequency comparable to MC concentrations in aquatic environments and thus may

120 pose problems for drinking water purification from surface water reservoirs (Beversdorf et

121 al., 2018, 2017; Janssen, 2019; Natumi and Janssen, 2020). Concentrations of

122 cyanopeptolines $\left(<7 \mathrm{ug} / \mathrm{L}^{-1}\right)$, anabaenopeptins $\left(<1 \mathrm{ug} / \mathrm{L}^{-1}\right)$ and microginins $\left(<1 \mathrm{ug} / \mathrm{L}^{-1}\right)$ have

123 been reported in surface waters (Beversdorf et al., 2017), however, more research is needed

124 regarding their diversity and concentration in aquatic environments. Furthermore, their effect

125 on organisms as a single compound or in a mixture are not investigated in detail.

126 Nevertheless, it has been suggested that in natural conditions some oligopeptides may be

127 even more harmful than MCs and other cyanotoxins to certain zooplankton species, in

128 particular as digestion inhibitors are active at much lower concentrations than the classical

129 cyanotoxins (Von Elert et al., 2004). Digestive enzyme inhibition would cause starvation,

130 impair growth and reproduction, eventually leading to slow death (Von Elert et al., 2004).

131 Among the freshwater zooplankton species, Daphnia graze on phytoplankton including

132 cyanobacteria, thereby connecting the primary production to the consumers within the

133 aquatic food web (Ger et al., 2016). Dominance of nutritionally inadequate phytoplankton,

134 such as cyanobacteria, which lack important sterols and fatty acids necessary for Daphnia

135 growth and development, can represent an obstacle in efficient carbon transfer to higher

136 trophic levels (Martin-Creuzburg et al., 2008). During their lifetime, however, Daphnia are

137 able to develop tolerance to cyanobacterial metabolites, as a physiological response to

138 bioactive compounds (Gustafsson and Hansson, 2004; Ortiz-Rodríguez et al., 2012; Sarnelle

139 and Wilson, 2005). Several mechanisms have been described so far, such as Daphnia's ability

140 to remodel their digestive enzymes (Schwarzenberger et al. 2012, von Elert et al. 2012), or

141 increase of antioxidant and biotransformation enzyme activity (Dao et al., 2013; Ortiz-

142 Rodríguez and Wiegand, 2010; Sadler and von Elert, 2014a). When exposed to 143 cyanobacterial metabolites that are chymotrypsin and trypsin inhibitors, Daphnia switch to 

chymotrypsins and trypsin isoenzymes with smaller molecular mass, which are less inhibited (Schwarzenberger et al. 2012, von Elert et al. 2012). The antioxidative enzymatic defenses include catalase (CAT), superoxide dismutase (SOD), glutathione-peroxidase (GPx), while glutathione S-transferase (GST) is the detoxification mechanism (Ighodaro and Akinloye, 2018; Pflugmacher et al., 1998). Daphnia can reduce oxidative stress caused by cyanobacterial metabolites by increasing CAT activity (Ortiz- Rodríguez and Wiegand, 2010; Wojtal-Frankiewicz et al. 2014). Similar increased activity of antioxidant SOD and CAT enzyme providing cellular protection against ROS is found in a study where Daphnia magna was fed with Microcystis diet (Lyu et al., 2016b). Daphnia can reduce the toxicity of microcystin by increasing the activity of GST catalysing the biotransformation via conjugation to glutathione (Dao et al. 2010; Ortiz-Rodríguez et al., 2012; Miles et al. 2016).

Furthermore, studies in Daphnia have shown that cyanobacterial metabolites can affect expression of genes involved in digestive system (Asselman et al., 2014; Drugă et al., 2016; Schwarzenberger et al., 2012), cell cycle (De Coninck et al., 2014b; Giraudo et al., 2017; Tong et al., 2017), and oxidative stress (De Coninck et al., 2014b; Lyu et al., 2016a; Rhiannon et al., 2011). However, characterizing transcriptional responses of Daphnia to cyanobacterial toxins so far focussed merely on effect of microcystin or cyanobacterial media without considering other bioactive molecules that might be present apart from microcystin (Asselman et al., 2012; De Coninck et al., 2014a; Drugă et al., 2016; Lyu et al., 2016b).

Besides being affected by grazing on cyanobacteria, zooplankton can also be affected by naturally produced cyanobacterial metabolites released in water (Barrios et al., 2015; FerrãoFilho et al., 2014; Smutná et al., 2014). Nevertheless, most of the studies investigate impact of cyanobacteria on Daphnia grazing on them, or exposure to extracts obtained by crushing cyanobacterial cells (from a culture or from a field sample), or to purified compounds (Dao et al., 2013; Esterhuizen-Londt et al., 2016; Peng et al., 2018). Hence, it is of interest to investigate if Daphnia are impaired by the presence of cyanobacterial metabolites naturally released during cyanobacterial normal growth, without necessarily feeding on them, or crushing cells. Furthermore, knowing the composition and concentration of metabolites present in the medium, naturally released as a product of cyanobacterial metabolic activity, would provide further understanding of Daphnia's response to cyanobacterial metabolites. 
174 Therefore, the aim and novelty of this study is Daphnia exposure to cell free cyanobacterial 175 spent medium obtained from a two weeks culture of exponentially growing $M$. aeruginosa, 176 containing metabolites naturally released during that time. In addition, we detected and 177 quantified cyanobacterial metabolites present in the medium, beside commonly investigated 178 microcystin. We monitored markers of stress response in order to predict Daphnia 179 physiological phenotypes as a response to cyanobacterial spent medium. We analyzed the 180 effects of cell free cyanobacterial spent medium that contained a quantified mixture of 181 compounds on i) Daphnia survival, ii) activity of enzymes involved in oxidative stress and 182 detoxification and iii) expression of candidate genes involved in digestion, growth and 183 development, detoxification and oxidative stress response. We hypothesize a negative impact 184 on Daphnia survival, a trigger of CAT and GST activities, as well as expression of genes 185 involved in Daphnia growth and development, digestion, detoxification and oxidative stress. 186 187 


\subsection{Culture conditions}

191

\subsubsection{Microcystis aeruginosa PCC 7806}

193

An axenic microcystin (MC) producing M. aeruginosa strain PCC 7806 was obtained from the Pasteur Culture collection of Cyanobacteria in Paris, France (https://research.pasteur.fr/en/team/collection-of-cyanobacteria/). The strain was grown in 100\% cyanobacterial BG11 medium (SIGMA), under a 14h:10h light:dark regime using

198 daylight white fluorescent tubes (Toshiba, $15 \mathrm{~W}$, FL15D) with $20 \mu \mathrm{mol}$ photons $\mathrm{m}^{-2} \mathrm{~s}^{-1}$ 199 illumination at a constant temperature of $20 \pm 1^{\circ} \mathrm{C}$ (Sanyo incubator). The culture was maintained in exponential growth phase, while the axenicity was regularly evaluated as 201 described in (Briand et al., 2012).

\subsubsection{Daphnia magna}

The D. magna clone was obtained from the PEARL INRA 1036 U3E. As the exposure to cyanobacteral metabolites was realized via $M$. aeruginosa PCC 7806 spent medium, the D. magna clone was acclimated to BG11 medium (SIGMA). Before performing experiments we compared osmolarity of BG 11 medium with the osmolarity of commonly used Artificial Daphnia medium, Elendt M4 and Elendt M7. Osmolarity of BG 11 medium was similar to

210 that of these Daphnia media, thus not affecting Daphnia survival. During the first three weeks

211 D. magna were slowly acclimated and adjusted to the cyanobacterial BG 11 medium that was

212 used in all the experiments, by gradually increasing the \% of BG11 medium until it reached

$213100 \%$ in the end of the acclimation period. After the acclimation period D. magna were grown 214 in $100 \%$ of BG11 medium for a month, before neonates $(<36 \mathrm{~h}$ old $)$ were used in the 215 experiment. During the acclimation and cultivation period no irregularities in Daphnia 216 survival, eating, movement and growth were noticed, suggesting that D. magna were 217 successfully acclimated to the medium (Bojadzija Savic et al., 2020). D. magna were grown 218 and cultivated in the aquarium at a constant temperature of $20^{\circ} \mathrm{C}$, light intensity of $15 \mu \mathrm{mol}$ 219 photons $\mathrm{m}^{-2} \mathrm{~s}^{-1}$ having a day/night cycle of 14h:10h (Sanyo MIR 154) and daily renewal of 
$20 \%$ of the medium. Daphnia were fed daily with a fresh sub-culture of the green algae

221 Scenedesmus communis originating from lake Grand Lieu, France, that was isolated in our laboratory (University of Rennes 1).

Sufficient food that 100 Daphnia (According to OECD guidelines for testing of chemicals 202) that should be available daily in the medium is equivalent to $2.8-5.6 \times 10^{8}$ cells/mL of $S$. communis. Daphnia are usually maintained in medium that is not appropriate for algal growth (Elendt M4, Elendt M7- OECD guidelines for testing of chemicals), therefore when S. communis are introduced to Daphnia medium, they are consumed before growing in high densities. However, in our cultures Daphnia were adjusted to BG11 medium that was also used for S. communis culture. Hence, it allowed S. communis to grow and reach high densities (10x higher than the initial one, within one week) while being consumed by Daphnia. As high density of $S$. communis disrupts normal Daphnia functioning; its concentration had to be adjusted to $2.8-5.6 \times 10^{7}$ cells $/ \mathrm{mL}$ to maintain equilibrium between growth and consumption. In order to keep the $S$. communis culture in more accessible form for consumption, in particular by neonates (i.e. unicellular /in pairs instead of four cells having long spikes), Scenedesmus culture was diluted every few days before feeding.

\subsection{Experimental design}

All experiments were performed in 5 replicates in $2 \mathrm{~L}$ aquariums and lasted for 3 and 7 days. All Daphnia were fed daily with S. communis, whose density was monitored and adjusted daily. For the control, 150 D. magna neonates $(<36 \mathrm{~h}$ old) per aquarium were raised in BG11.

For the treatment, the cyanobacterial spent media was prepared in the following way: from an exponentially growing $M$. aeruginosa PCC 7806 culture, centrifuged cells were transferred in fresh sterile BG 11 medium to remove extracellular metabolites. From the pellet, a cyanobacterial culture of $2 \times 10^{5}$ cells $/ \mathrm{mL}$ initial density was grown for two weeks, reaching a cell density of $1 \times 10^{6}$ cell/mL. From that culture, cell free cyanobacterial spent medium was collected by filtering through $0.2 \mu \mathrm{m}$ sterile cellulose nitrate filter. D. magna were exposed to two concentrations of cyanobacterial spent medium: a) diluted with the BG11 in the ratio 1:40 (thereafter called $\mathrm{HC}$ for high concentration) and b) 1:400 (thereafter 
called LC for low concentration). These 2 dilutions provided environmentally relevant concentrations of MC-LR in our experiments (final concentration of MC-LR: LC: $0.5 \mu \mathrm{g} / \mathrm{L}$, HC: $5 \mu \mathrm{g} / \mathrm{L}$ ), as dissolved MC ranges in the environment between 0.2 and $11 \mu \mathrm{g} / \mathrm{L}$ (Lahti et al., 1997; Pawlik-Skowrońska et al., 2008; Rastogi et al., 2015; Su et al., 2015).

D. magna neonates (150 per treatment) were exposed to $2 \mathrm{~L}$ of these two concentrations. At the end of the exposure (3 days and respectively 7 days), D. magna samples (biotransformation, oxidative stress, energetic profiles) were taken by collecting them over a mesh, briefly rinsed with fresh BG11 media, and after removal of the excess media, snap frozen in liquid nitrogen and stored at $-80^{\circ} \mathrm{C}$ until analysis.

\subsection{Cyanobacterial secondary metabolites analysis}

Cyanobacterial secondary metabolites previously known to be produced by this particular strain PCC7806 (Briand et al., 2016; Rohrlack et al., 2004; Sadler and von Elert, 2014b) were monitored after 2 weeks growth phase from initially $2 \times 10^{5}$ cells $/ \mathrm{mL}$ to $1 \times 10^{6}$ cells/mL. Cyanobacterial cells were separated from the supernatant by centrifugation. Cell free spent medium was filtered through $0.2 \mu \mathrm{m}$ filter and $1 \mathrm{~mL}$ was lyophilized. Extraction of lyophilized material was done in $0.5 \mathrm{ml} 50 \%$ methanol and processed as described in Bojadzija Savic et al., 2019. Waters Acquity Ultra-High Performance Liquid Chromatography coupled to a Xevo quadrupole time of flight mass spectrometer was used for the metabolites analysis. Cyanobacterial peptides were detected using extracted ion chromatograms for the respective specific masses of the different compounds (Bojadzija Savic et al., 2019). Microcystin-LR (MC-LR), Microcystin-des-LR (des-MC-LR), cyanopeptolin A (CP-A), and aerucyclamide A (AC-A) and D (AC-D) were quantified using linear relationship between peak area (MC-LR and des-MC-LR at $238 \mathrm{~nm}, \mathrm{CP}-\mathrm{A}$ at $220 \mathrm{~nm}$, and AC-A at $237 \mathrm{~nm}$ and AC-D at $240 \mathrm{~nm}$ ) and known concentrations of the toxin standards. The microcystin-LR standard was purified as previously described (Edwards et al., 1996). CP-A standard and AC-A and AC-D standard were purified using preparative HPLC (Biotage Parallex Flex, Cardiff, UK) and Flex V3 software for instrument control and data acquisition as described in (Bojadzija Savic et al., 2020). Detection and quantification of the cyanobacterial peptides was done by MassLynx v4.1 software. 
Survival of D. magna was monitored daily, by counting and removing dead Daphnia (identified as not moving and decaying Daphnia on the bottom of the aquarium) with results expressed in percentages of total individuals at the start of the exposure.

\subsection{Enzyme extraction and measurement}

Fifty Daphnia were resuspended and homogenized in $1 \mathrm{~mL}$ of ice cold extraction buffer (0.1 M phosphate buffer $\mathrm{pH}$ 6.5, glycerol, $1 \mathrm{mmol}$ EDTA, and $1.4 \mathrm{mmol}$ dithioerythritol) using Lysing Beads-Matrix E (MPbio) in the Vibro-mill MM200, (RETSCH) for 3 min at the frequency of $25 \mathrm{~Hz}$ to break the cells, followed by centrifugation $\left(10,000 \mathrm{~g}, 10 \mathrm{~min}, 4^{\circ} \mathrm{C}\right.$, Sigma 3K18C). The supernatant was used for enzyme measurements using a spectrofluorometer (SAFAS Monaco Xenius XC, Monaco). Catalase (CAT) activity was assayed by measuring the rate of disappearance of $\mathrm{H}_{2} \mathrm{O}_{2}$ at $240 \mathrm{~nm}$ (Chang and Kao, 1997). GST was assayed at $340 \mathrm{~nm}$ using 1-chloro-2, 4-dinitrobenzene (CDNB) as substrate. SOD activity was determined using a photochemical assay based on the reduction of nitro blue tetrazolium (NBT) according to total Superoxide Dismutase (T-SOD) assay kit (Hydroxylamine method, SIGMA KIT), however SOD activity in our experiments remained below the level of detection. All enzyme activities were related to the protein content in the extract, measured according to Bradford (1976).

\subsection{Candidate function gene expression}

\subsubsection{RNA extraction and reverse transcription}

RNA extraction and reverse transcription was done according to (Colinet et al. 2010) from the unexposed control and from Daphnia exposed to LC and HC after 3 and 7 days. For each condition and sampling time point, five RNA samples (i.e. biological replicates), each consisting of a pool of 50 Daphnia, were used. Daphnia were ground to fine powder in 1.5 $\mathrm{mL}$ tubes placed in liquid nitrogen. Samples were mixed with lysis buffer (containing 1\% $\beta$ mercaptoethanol) from RNA extraction kits (Qiagen) and crushed for $10 \mathrm{~min}$ to complete homogenization. RNA extraction and purification was performed following the manufacturer's instructions (Qiagen). Total RNA was eluted in $40 \mu \mathrm{L}$ of DEPC-treated water. RNA was quantified and quality-checked with a Nanodrop 1000 (Thermo Scientific, Waltham, MA). Three hundred nanograms of total RNA was used in the reverse transcription to cDNA, using the SuperScript ${ }^{\circledR}$ III First-Strand Synthesis System for RT-PCR 
320 (Invitrogen), according to the manufacturer's instructions. The undiluted cDNA was stored 321 at $20^{\circ} \mathrm{C}$ until use.

322

323

324

325

326

327

328

329

330

331

332

\subsubsection{Real-time PCR}

We used primers of candidate genes involved in Daphnia energy (glyceraldehyde-3phosphate dehydrogenase: gapdh), digestive system (protease: ct383), oxidative stress (glutathione S-transferase: gst, glutathione peroxidase: $g p x$, catalase: cat, thioredoxin: $\operatorname{trx}$,), cell cycle (histone: $h 2 a$, myosin heavy chain: $m h c r t$ ) and molting (nuclear hormone receptor: $h r 3$, nuclear hormone receptor: $f t z-f 1)$ that potentially could be affected by cyanobacterial metabolites. We used $\boldsymbol{\beta}$-actin as the reference gene. Oligonucleotide primers were obtained from the previously published references (see Table 1. for details), having efficiency between 92\% and 105\% (Giraudo et al., 2017; Houde et al., 2013; Lyu et al., 2014; Rhiannon et al., 2011; Schwarzenberger et al., 2010; Tong et al., 2017; Wang et al., 2016). Oligonucleotide primers were made by Integrated DNA Technologies, BVBA.

Table 1. Oligonucleotide primers used in the experiments.

\begin{tabular}{|c|c|c|c|c|}
\hline Gene name & Symbol & Primer sequence $5^{\prime}-3^{\prime}$ & $\begin{array}{l}\text { Amplicon } \\
\text { size }\end{array}$ & Reference \\
\hline $\begin{array}{l}\text { Glyceraldehyd } \\
\text { e-3-phosphate } \\
\text { dehydrogenase }\end{array}$ & gapdh & $\begin{array}{l}\text { F- TGCTGATGCCCCAATGTTTGTTGT } \\
\text { R-GCAGTTATGGCGTGGACGGTTGT }\end{array}$ & 132 & $\begin{array}{l}\text { (Giraudo et al., } \\
\text { 2017) }\end{array}$ \\
\hline $\begin{array}{l}\text { Protease } \\
\text { CT383 }\end{array}$ & ct383 & $\begin{array}{l}\text { F- TTGGCACCTTCCACCGAAT } \\
\text { R- TCATCAGGACTGGAGAAACGC }\end{array}$ & 183 & $\begin{array}{l}\text { (Schwarzenberge } \\
\text { ret al., 2010) }\end{array}$ \\
\hline $\begin{array}{l}\text { Glutathione S- } \\
\text { transferase } \\
\text { (NCBI: No. } \\
\text { EFX81634.1) }\end{array}$ & gst & $\begin{array}{l}\text { F- GGGAGTCTTTTACCACCGTTTC } \\
\text { R- TCGCCAGCAGCATACTTGTT }\end{array}$ & 150 & $\begin{array}{l}\text { (Wang et al., } \\
\text { 2016) }\end{array}$ \\
\hline $\begin{array}{l}\text { Glutathione } \\
\text { peroxidase }\end{array}$ & $g p x$ & $\begin{array}{l}\text { F- AACGTTACGATGCCAGTTCC } \\
\text { R- TCTTTCGAGCGGTTGAGATT }\end{array}$ & 212 & $\begin{array}{l}\text { (Rhiannon et al., } \\
\text { 2011) }\end{array}$ \\
\hline Catalase & cat & $\begin{array}{l}\text { F- AGGTGCCTTTGGATACTTTGA } \\
\text { R- TTGCGTATTCCTTGGTCAGTC }\end{array}$ & 495 & $\begin{array}{l}\text { (Lyu et al., } \\
\text { 2014) }\end{array}$ \\
\hline Thioredoxin & $t r x$ & $\begin{array}{l}\text { F- GTATCCACGCCAGTCCTTGTT } \\
\text { R- TCCTTCCACTTTTCCTCCCTTA }\end{array}$ & 129 & (Liu et al., 2019) \\
\hline Histone 2A & $h 2 A$ & $\begin{array}{l}\text { F- CTGGTGCCCCTGTCTACCTA } \\
\text { R- TAGGGAGGAGAACAGCCTGA }\end{array}$ & 219 & $\begin{array}{l}\text { (Giraudo et al., } \\
\text { 2017) }\end{array}$ \\
\hline $\begin{array}{l}\text { Myosin heavy } \\
\text { chain }\end{array}$ & mhcrt & $\begin{array}{l}\text { F - GATGCCGTTTCCGAGATGAG } \\
\text { R - CTCGGCGGTCATGTGGTC }\end{array}$ & 132 & $\begin{array}{l}\text { (Tong et al., } \\
\text { 2017) }\end{array}$ \\
\hline
\end{tabular}




\begin{tabular}{|c|c|c|c|c|}
\hline $\begin{array}{l}\text { Nuclear } \\
\text { hormone } \\
\text { receptor HR3 }\end{array}$ & $h r 3$ & $\begin{array}{l}\text { F- AAGGTCGAGGATGAAGTGCG } \\
\text { R- AAAGACGCTACTATCGGGCG }\end{array}$ & 81 & $\begin{array}{l}\text { (Giraudo et al., } \\
\text { 2017) }\end{array}$ \\
\hline $\begin{array}{l}\text { Nuclear } \\
\text { hormone } \\
\text { receptor FTZ- } \\
\text { F1 }\end{array}$ & $f t z-f 1$ & $\begin{array}{l}\text { F- TCTTACCGGACATTCACGCC } \\
\text { R- ACAGCCGTTGAGATGCTTGA }\end{array}$ & 71 & $\begin{array}{l}\text { (Giraudo et al., } \\
\text { 2017) }\end{array}$ \\
\hline Beta-actin & $\beta$-actin & $\begin{array}{l}\text { F- GCCCTCTTCCAGCCCTCATTCT } \\
\text { R- TGGGGCAAGGGCGGTGATTT }\end{array}$ & 189 & $\begin{array}{l}\text { (Houde et al., } \\
\text { 2013) }\end{array}$ \\
\hline
\end{tabular}

337 Real-time PCRs were performed on the LightCycler 480 system. Reactions were performed 338 in 384-well LightCycler plates, using LightCycler 480 High Resolution Melting Master Mix 339 and the crossing point $(\mathrm{Cp})$, equivalent to the cycle threshold $(\mathrm{Ct})$, estimates were obtained 340 using the absolute quantification module in the software package. The PCR reactions were 341 performed in four replicates, containing $4 \mu \mathrm{L}$ of cDNA sample, $2 \mu \mathrm{m}$ each primer, and $6 \mu \mathrm{L}$ 342 of the High Resolution Melting Master Mix. After 10 min at $95^{\circ} \mathrm{C}$, the cycling conditions 343 were as follows: 60 cycles at $95^{\circ} \mathrm{C}$ for $10 \mathrm{~s}, 60^{\circ} \mathrm{C}$ for $15 \mathrm{~s}$, and $72^{\circ} \mathrm{C}$ for $15 \mathrm{~s}$. To validate the 344 specificity of amplification, a post amplification melt curve analysis was performed. 345 Amplicons were first denatured at $95^{\circ} \mathrm{C}$ for $1 \mathrm{~min}$, and then cooled to $65{ }^{\circ} \mathrm{C}$, and the 346 temperature was then gradually raised to $95^{\circ} \mathrm{C}$ ). Fluorescence data were recorded 347 continuously during this period, and subsequently analyzed using the Tm calling module in 348 the LightCycler 480 software.

$$
R=\frac{\left(E_{\text {target }}\right)^{\Delta C P \operatorname{Ctarget}(\text { control-treated sample })}}{\left(E_{\text {reference }}\right)^{\Delta C P \operatorname{target}(\text { control-treated reference })}}
$$

350 Relative expression ratios (R) (i.e. fold change) were calculated using the efficiency 351 calibrated model of (Colinet et al., 2010; Pfaffl, 2001). In the Pfaffl model, CP is the crossing 352 point (i.e. $\mathrm{Ct}$ ) and $\mathrm{E}$ the efficiency of PCRs. qPCR CT values of all candidate genes have 353 been provided in Supplementary 1. The ratio of the target gene is expressed in treated 354 samples versus matched controls (calibrators), and normalized using the housekeeping 355 reference gene.

\subsection{Statistical analyses}

R Core Team (2013) was used to access statistical analysis of the obtained data. All data are presented as mean \pm standard deviation. Significant differences were determined at 12 
$361 \mathrm{p}<0.05$. We performed t-tests to determine the difference between CAT, GST activities, as

362 well as gene expression between the control and treatment. Repeated-measures analysis of

363 variance was done to determine the difference in Daphnia survival between Control/LC,

364 Control/HC and LC/HC ). Repeated-measures analysis of variance is a mixed linear model

365 with day, treatment (Control vs Treatment) and interaction between day and treatment

366 considering the repeated measures on replicates (random effect). Normality of residuals was

367 tested via Shapiro test (residuals normaly distributed when $\mathrm{p}>0.05$ ). Anova was performed

368 to test the effects of the model. Pairwise comparison with correction for multiple comparison

369 was performed to check significant differences between control and the two treatments,

370 differences between LC and HC and if there was time dependency effect on control and 371 treatment. 


\subsection{Composition of the two weeks old M. aeruginosa PCC7806 medium}

In the media produced by exponentially growing $M$. aeruginosa PCC7806, 11 metabolites were detected after 2 weeks of cultivation. M. aeruginosa PCC 7806 produced MC-LR and des-MC-LR, cyanopeptolins, CP (963A, A and B), aerucyclamides, AC (A,B,C and D) and aeruginosins (684 and 602) (Figure 1.).

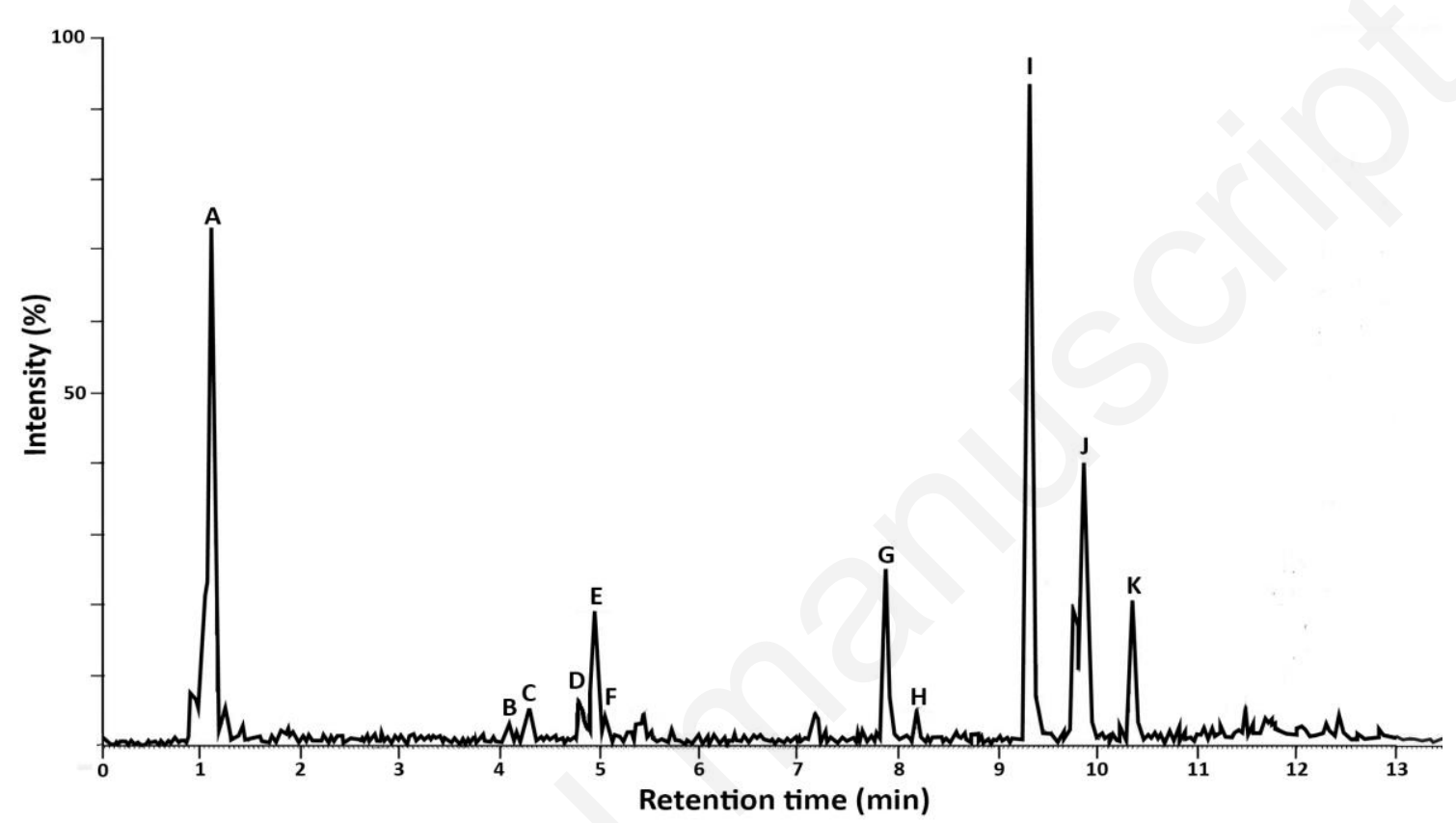

Figure 1. Secondary metabolites detected in M. aeruginosa PCC 7806. (A) aeruginosin 684, (B) 386 cyanopeptolin B, (C) aeruginosin 602, (D) des-MCLR, (E) MC-LR, (F) CP A, (G) aerucyclamide D, (H) cyanopeptolin 963A, (I) aerucyclamide A, (J) aerucyclamide C, (K) aerucyclamide B.

The concentrations of five extracellular metabolites (MC-LR, des-MC-LR, CP-A, ACD, AC-A) in M. aeruginosa PCC 7806 after 2 weeks growth phase from $2 \times 10^{5}$ cells $/ \mathrm{mL}$ initially to $1 \times 10^{6}$ cells $/ \mathrm{mL}$, and in dilutions $\mathrm{HC}$ and $\mathrm{LC}$ are shown in Table 2.

Table 2. Concentrations of extracellular metabolites in original medium of the 2 weeks $M$. aeruginosa PCC 7806 and its HC and LC dilutions

\begin{tabular}{llll}
\hline Extracellular metabolite & \multicolumn{1}{l}{ Original spent $M$. aeruginosa } & $\mathrm{HC}(\mu \mathrm{g} / \mathrm{L})$ & $\mathrm{LC}(\boldsymbol{\mu g} / \mathrm{L})$ \\
& PCC 7806 medium $(\mu \mathrm{g} / \mathrm{L})$ & \\
\hline MC-LR & $\mathbf{2 1 8} \pm \mathbf{2 1}$ & $\mathbf{5 . 4 5} \pm \mathbf{0 . 5 3}$ & $\mathbf{0 . 5 5} \pm \mathbf{0 . 0 5}$ \\
Des-MC-LR & $\mathbf{6 1 \pm 1}$ & $\mathbf{1 . 5 3} \pm \mathbf{0 . 0 3}$ & $\mathbf{0 . 1 5} \pm \mathbf{0 . 0 1}$ \\
CP-A & $\mathbf{1 3 5} \pm \mathbf{1 1}$ & $\mathbf{3 . 3 8} \pm \mathbf{0 . 2 8}$ & $\mathbf{0 . 3 4} \pm \mathbf{0 . 0 3}$ \\
AC-D & $\mathbf{9 3} \pm \mathbf{1 0}$ & $\mathbf{2 . 3 3} \pm \mathbf{0 . 2 5}$ & $\mathbf{0 . 2 3} \pm \mathbf{0 . 0 2}$
\end{tabular}




\subsection{Daphnia survival}

The high concentration of the cyanobacterial medium (HC) caused a significant decrease in survival from day 2 onwards, compared with the control, while exposure to the low concentration (LC) caused significant decrease after day 3. Both concentration levels significantly decreased Daphnia survival over the course of the experiment. Daphnia survival was significantly higher in LC exposure from day 3 onwards (80\% survival after 7 days) compared with the HC exposure (40\% survival after 7 days) (Figure 2.)

401

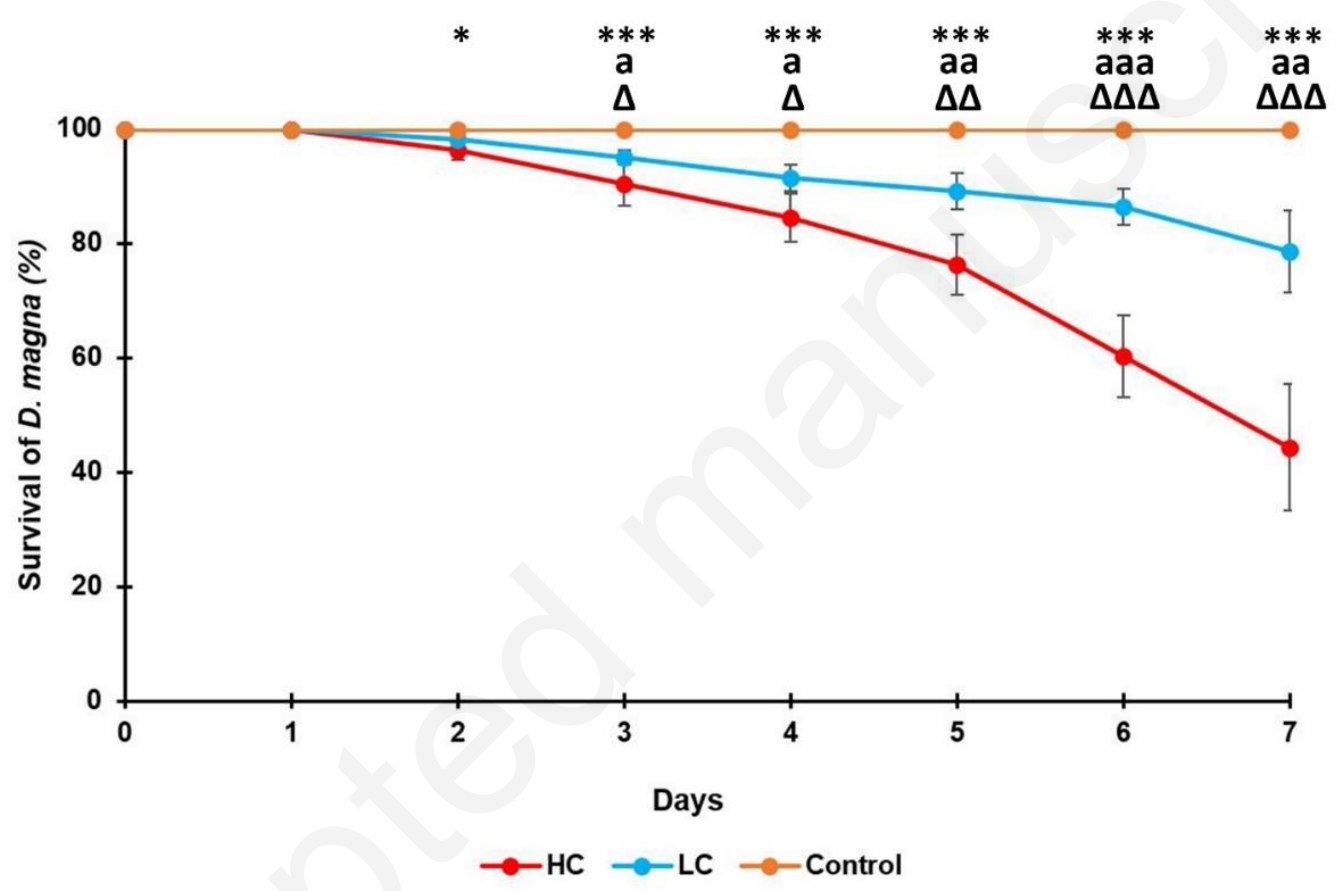

Figure 2. D.magna survival when exposed to HC and LC. Control vs HC: *; Control vs LC: a ; HC vs LC: $\Delta$. *, a, $\Delta(\mathrm{p}<0.05),{ }^{* *}$, aa, $\Delta \Delta(\mathrm{p}<0.01),{ }^{* * *}$, aaa, $\Delta \Delta \Delta(\mathrm{p}<0.01)$; repeated-measures analysis of variance

\subsection{Antioxidant and detoxification enzymes}

CAT activity was significantly lower on day 3 and day 7 in the LC exposure, compared to the control. Similarly GST activity was significantly lower on day 3 and 7 in the treatment exposed to LC, compared to the control. Due to the high mortality in the HC exposure, the biomass of the remaining Daphnia was insufficient for enzyme analysis on both days (Figure 3.). 


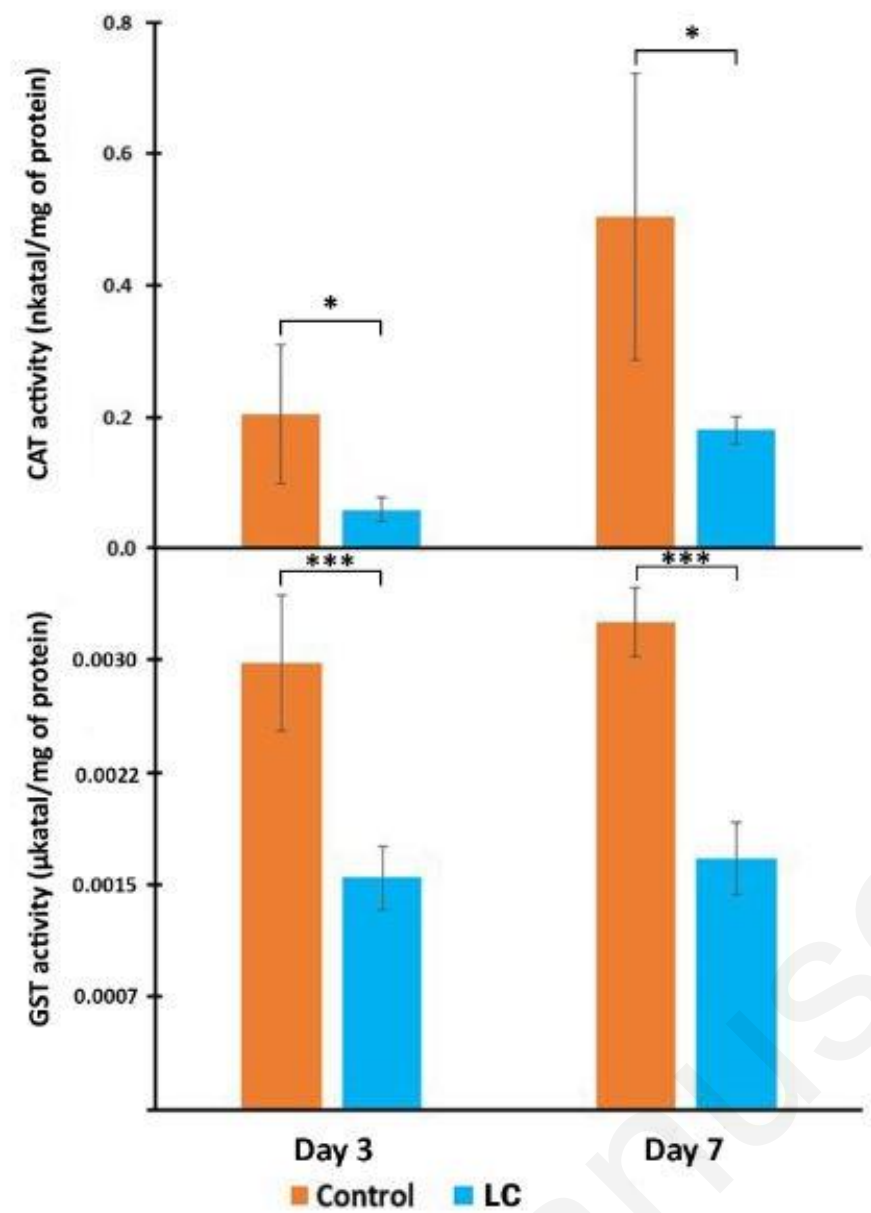

Figure 3. CAT and GST activity in D.magna exposed to LC * $(\mathrm{p}<0.05), * *(\mathrm{p}<0.01)$, *** $(\mathrm{p}<0.01)$, t-test

\subsection{Selected genes expression}

Glyceraldehyde 3-phosphate dehydrogenase (gapdh) was significantly overexpressed on day 3 when Daphnia were exposed to both HC and LC, but downregulated after 7 days, significant for LC (Figure 4. A). The gene coding for digestive enzyme Protease CT383 (ct383) was significantly downregulated after 3 days exposure to LC (day 3) of Microcystis spent medium, but not in the other treatment (Figure 4. B). Concerning the oxidative stress and detoxification related genes, merely downregulation was observed. The only exception was the gene encoding for the detoxification enzyme Glutathione S-transferase ( $g s t)$ which was significantly upgulated on day 3 when exposed to $\mathrm{HC}$, while on day 7 , gst was downregulated at LC treatment (Figure 4. C). Furthermore, Glutathione peroxidase ( gpx) expression was significantly downregulated on day 7 after Daphnia exposure to LC (Figure 4. D). Genes responsible for oxidative stress enzymes Catalase (cat) (Figure 4. E) and Thioredoxin (trx) (Figure 4. F) were downregulated on day 3 (LC) and day 7 (HC and LC). The response of the histone $2 \mathrm{~A}(h 2 A)$ gene was the opposite of this, when exposed to HC and 
431 LC: $h 2 A$ showed significant overexpression respectively downregulated on day 7 when 432 exposed to HC or LC (Figure 4. G). HC and LC also had significant negative effect on gene 433 expression of Myosin heavy chain ( $m h c r t$ ) that was significantly underregulated on day 3 and 4347 (Figure 4. H). Cyanobacterial secondary metabolites affected two genes involved in the 435 molting cycle: the Nuclear hormone receptor HR3 ( $h r 3)$ and FTZ-F1 ( $f t z-f 1)$. While the $h r 3$ 436 was significantly upregulated on day 3 when exposed to both HC and LC (Figure 4. I) ftz437 was significantly downregulated on day 7 when exposed to both HC and LC (Figure 4. J). 438 


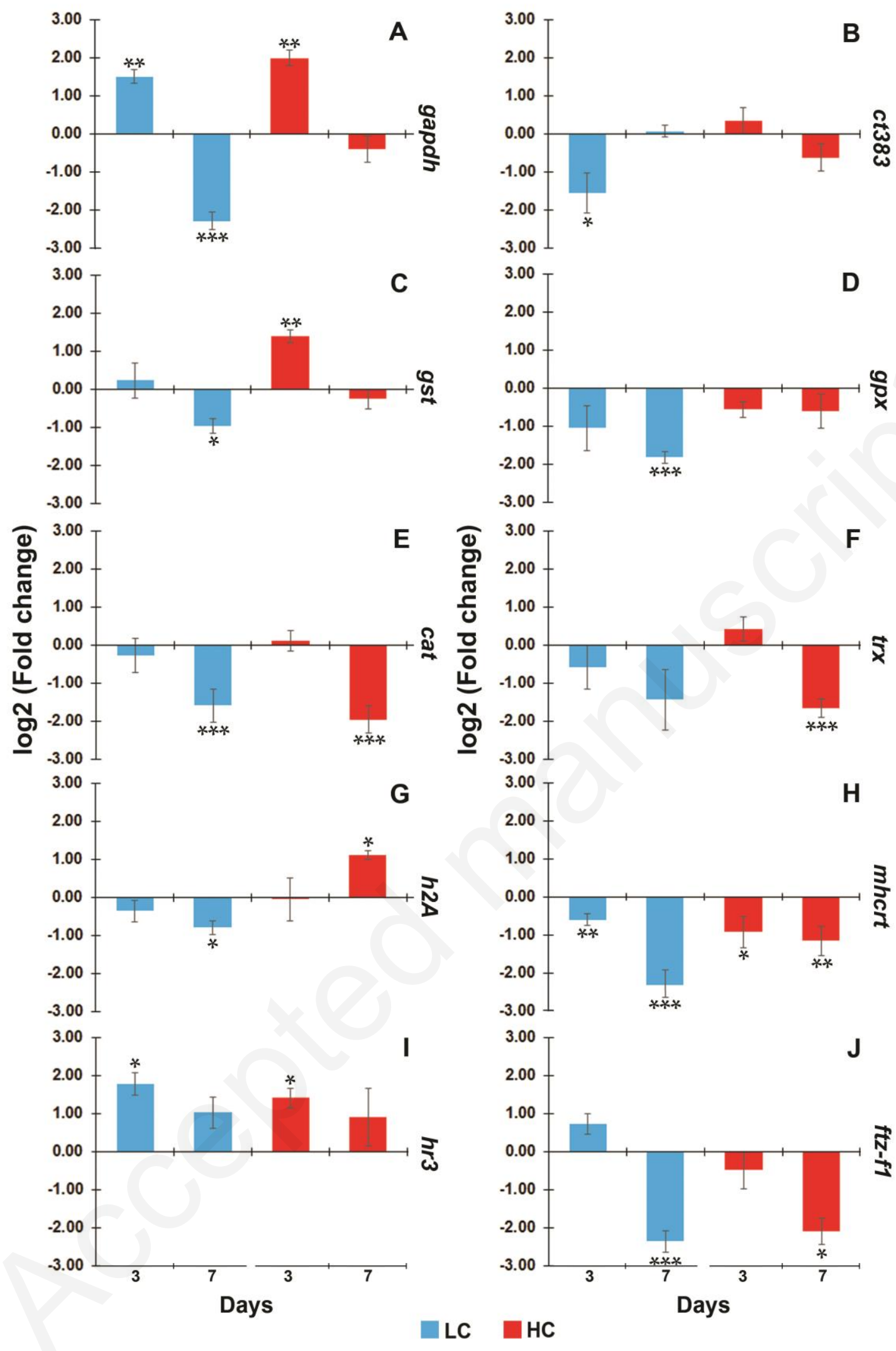

Figure 4. Effect of cyanobacterial media (LC and HC) on the relative gene expressions expressed as $\log 2$ (fold change). Relative expressions in D. magna for: A) Glyceraldehyde 3-phosphate dehydrogenase (gapdh), B) Protease CT383 (ct383), C) Glutathione S-transferase (gst), D) Glutathione peroxidase (gpx) E) Catalase $(c a t), \mathrm{F})$ Thioredoxin $(t r x), \mathrm{G})$ histone 2A $(h 2 A), \mathrm{H})$ Myosin heavy chain $(m h c r t), \mathrm{I})$ Nuclear hormone receptor HR3 ( $h r 3)$, J) Nuclear hormone receptor FTZ-F1 ( $t t-f 1)$. Gene expressions were normalized to the control condition for each sampling time. Replicates of culture are represented as a mean and error bars represent the standard deviations $(\mathrm{n}=5)$. $^{*}(\mathrm{p}<0.05), * *(\mathrm{p}<0.01), * * *(\mathrm{p}<0.01)$, t-test 
Daphnia are unselective phytoplankton filter feeders, and as such can be exposed to cyanobacterial metabolites by direct grazing on cyanobacteria as well as by uptake of metabolites released in the water. While previous studies have demonstrated the negative impacts of cyanobacterial medium (Lanaras and Cook 1994, Neumann et al. 2000, Dao et al. 2010, 2013, Esterhuizen-Londt et al. 2016, Peng et al. 2018) on Daphnia, the novelty of this study was to connect responses from selected markers on the gene-level to enzymatic activities and to consequences for the survival of D. magna exposed to cyanobacterial cellfree sprent medum. From the mixture of cyanobacterial metabolites in the medum we identified 11 and quantified 5.

As $M$. aeruginosa was grown in BG11, D. magna had to be acclimatised to this medium during several weeks before the experiment. Survival of the control group throughout the experiment was always high $(>98 \%)$. These results are in line with the literature where nontreated D. magna survival was always high (close to 100\%) in the first 8 days of experiments, although specific D. magna cultivation medium was used (Dao et al. 2010, Ortiz-Rodríguez et al. 2012), suggesting that BG 11 medium used in our study did not have impact on the $D$. magna survival. Apart from increased CAT activities no other changes were observed in the control group over the exposure time, we nevertheless suggest for further studies to compromise between both media by adding necessary minerals, e.g. calcium, using diluted BG 11, while keeping the osmolarity as we ensured in our exposures.

Cyanobacterial spent medium had a dose and time dependent negative impact on $D$. magna survival, verifying our hypothesis. The concentrations used (Table 2.) were detrimental thus preventing D. magna from acclimatisation during the exposure period. These detrimental effects within 7 days were not expected as these concentrations were chosen according to previous studies showing that survival of $D$. magna rapidly decreased during 3 weeks exposure to crude extract containing $50 \mu \mathrm{g} / \mathrm{L}$ of dissolved microcystin, while exposure to $5 \mu \mathrm{g} / \mathrm{L}$ did not impact Daphnia survival much (Dao et al., 2010). Similar results were observed by Lürling and van der Grinten (2003) where exposure to $3.5 \mu \mathrm{g} / \mathrm{L}$ of dissolved microcystin showed no significant decrease in survival over 7 days. When exposed to crude extract or artificial mixtures of pure microcystins containing $60 \mu \mathrm{g} / \mathrm{L}$ of total MC (MC-LR 
$21.1 \pm 1.9 \mu \mathrm{g} / \mathrm{L} ; \mathrm{MC}-\mathrm{RR} 37.2 \pm 4.8 \mu \mathrm{g} / \mathrm{L}$ and MC-YR $6.1 \pm 0.8 \mu \mathrm{g} / \mathrm{L})$ it did not appear to have an impact on D. pulex survival for 6 days (Esterhuizen-Londt et al., 2016). Our results 481 are, however, in line with studies exposing D. magna to $M$. aeruginosa containing 1.4-9 $\mu \mathrm{g} / \mathrm{L}$ 482 of MC, where feeding was inhibited, followed by increase of mortality in the first week of 483 the treatment (DeMott, 1999; Demott et al., 1991; Ghadouani et al., 2004; Rohrlack et al., 2001). D. laevis (two clones) and D. similis exposed to five Microcystis extracts in which microcystins were detected (434 - $538 \mathrm{mg} / \mathrm{g}$ of lyophilized sample) suffered decreased survival, reproduction and disturbance in egg production after $48 \mathrm{~h}$ (Herrera et al. 2015). Crude extract obtained from Microcystis spp. had lethal effect on D. magna neonates, with LC50 (48 h) ranging from 168.3-442.7 mg microcystin (total) $\mathrm{DW} \mathrm{L}^{-1}$ (Pham, 2018). Susceptibility to microcystin is, however, not only species-specific, but Daphnia species can also show different responses within their clones (DeMott, 1999; Hairston et al., 1999; Rohrlack et al., 2001).

As both concentrations in our experiment caused mortality (20\% for LC and $60 \%$ for HC) within the 7 days exposure, we suggest a high $D$. magna sensitivity to the other cyanobacterial metabolites present in the spent medium, as besides MC-LR and desmethyl MC-LR, cyanopeptolin-A, aerucyclamides A and D were quantified, and aeruginosins (602 and 684), cyanopeptolins (B and 963) and aerucyclamides (B and C) detected. HC and LC of Microcystis spent medium downregulated a gene encoding the digestive enzyme protease, ct383, thus potentially interfered with D. magna digestion and as a consequence could contribute to the increasing mortality in a concentration and time dependent manner. Similarly, when D. magna were fed with MC-producing strain of PCC 7806 wild type, ct383 was downregulated after 6 days, leading to reduced total chymotrypsin activity (Schwarzenberger et al., 2010).

When fed with Microcystis strain UWOCC MRC (a non-microcystin producing strain) a lethal molting disruption in Daphnia spp. has been observed, suggesting that cyanobacterial proteases, other than microcystin, could interfere with the molting cycle (Kaebernick et al.,

506 2001). Despite the absence of microviridins $\mathrm{J}$ in our medium, known to impair the molting 507 cycle in Daphnia via protease inhibition (Rohrlack et al., 2004), upregulation of a gene 508 coding for nuclear hormone receptor $(h r 3)$ followed by significant downregulation of $f t z-f 1$ 
transcripts involved in crustacean molting and development (Street et al., 2019) has been observed. Our results suggest that other metabolites have a role in impairment of these pathways which may affect Daphnia molting.

Activity of anti-oxidative stress enzymes is a crucial defense mechanism against the induction of oxidative stress by microcystins (Amado and Monserrat, 2010). Through increased oxidative stress enzyme activities and detoxication, D. magna are able to enhance acclimation to cyanobacterial metabolites (Ortiz-Rodríguez et al., 2012). CAT is a highly efficient antioxidant enzyme, responsible for reduction of $\mathrm{H}_{2} \mathrm{O}_{2}$ concentrations in the cells (Fridovich, 1998). Elevated CAT activity can prevent oxidative damage caused by cyanotoxins thus provides oxidative protection for Daphnia (Wojtal-Frankiewicz et al., 2013). Increased CAT activity was observed in adults and neonates after $24 \mathrm{~h}$ when exposed to $100 \mu \mathrm{g} / \mathrm{L}$ pure MC-LR, while exposure to $5 \mu \mathrm{g} / \mathrm{L}$ MC-LR or less, CAT activity was similar to control (Ortiz-Rodríguez et al., 2012). In our experiments, genes of antioxidant enzymes, cat and trx, were downregulated, confirming the results of the enzyme activity. The significant decrease in CAT activity on days 3 and 7, suggests that these enzymes were exhausted due to the presence of the mixture of cyanobacterial compounds in the concentrations applied. Similarly, CAT decreased in D. magna after being exposed to cyanobacterial crude extract (containing $60 \mu \mathrm{g} / \mathrm{L}$ total MC) during the whole exposure period of $72 \mathrm{~h}$ while the pure toxin MC-LR increased its activity (Esterhuizen-Londt et al. 2016). Even when D. magna were exposed to extracts from non-microcystin and noncylindrospermopsin medium, their CAT decreased after day 1 and 7 (Dao et al., 2013). In combination with the observed lethality, our results suggest that D. magna oxidative defence response was repressed in such way that oxidative damages may have occurred resulting in lethal effects.

In D. magna and D. longispina, increased GST activity can detoxify microcystin up to a certain concentration or exposure duration, which can also be transferred to the next generation (Ortiz-Rodrigues et al., 2012; Wojtal-Frankiewicz et al. 2013, 2014). Despite the upregulation of $g s t$ within the first 3 days, our exposures, however, decreased GST activity, compared with the control on day 3 and day 7, where expression of gst gene was downregulated as well. Our GST results concern one or at maximum two out of on average 
7 GST isoenzymes present in an organism, hence genes regulating other GST isoenzymes

540 may have had a different response. Asselman et al. (2012) showed that sigma-class gst genes

541 in D. pulex were upregulated when fed on MC-producing M. aeruginosa after 16 days.

542 However, our results are in line with previous studies where short term exposure $(48 \mathrm{~h})$ to

543 microcystin-producing M. aeruginosa PCC7806 increased delta-gst transcript levels, while

544 long term exposure (15 days) downregulated them (Lyu et al., 2016a). Similar decrease in

545 GST activities were observed in D. magna exposed to cyanobacterial medium (containing 60

$546 \mu \mathrm{g} / \mathrm{L}$ total MC) after $24 \mathrm{~h}$ and $72 \mathrm{~h}$ (Esterhuizen-Londt et al., 2016). Furthermore, GST

547 activity in D. magna decreased with increased MC-LR concentrations from 10 to $2000 \mu \mathrm{g} / \mathrm{L}$

548 (Chen et al., 2005), suggesting enzymes exhaustibility as also seen in (Dao et al., 2013).

549 Our results suggest that even lower concentrations of MC in the cyanobacterial medium,

550 along with the other cyanobacterial metabolites can affect enzyme activity in a similar way

551 like cyanobacterial medium containing higher microcystin concentrations. Besides

552 cyanobacterial metabolites that were detected, cyanobacterial medium could contain

553 undetected compounds that could potentially interfere with overall ecotoxicity (Smutná et

554 al., 2014) or inhibit enzymes activity, such as microcin SF608 that was shown to have

555 inhibitory impact on GST (Wiegand et al., 2002).

556 When Daphnia are in toxic environments, mobilization of detoxification and antioxidant

557 defense mechanisms, as well as growth and development, comes with energetic cost (Calow,

558 1991; McKee and Knowles, 1986; Pane et al., 2004). For instance, D. magna exposed to

559 nickel (Pane et al., 2004) or the fungicide tebuconazole (McKee and Knowles, 1986) showed

560 increased energy consumption, as glycogen and lipids levels were decreased. In our

561 experiments energetic resouces were instantly used, visible by the induction of gapdh

562 (involved in glycolysis) at day 3. Upregulation of gapdh has been observed in D. magna in

563 response to diet containing microcystins after 4 days of the experiment, suggesting that

564 ingestion of microcystin induces glycolysis and protein catabolism (Schwarzenberger et al.,

565 2009). Our results further suggest that severe depletion of energy affected also the muscular

566 activity, as the myosin heavy chain was immediately and significantly downregulated in both

567 experimental exposures (HC and LC). Depletion of energy in combination with

568 downregulation of the myosin heavy chain could provide a mechanistic explanation of the 
locomotory inhibition (feeding and swimming) observed in previous studies (e.g. Rohrlack et al., 2001; Ghadouani et al., 2004).

The response of the histone $2 \mathrm{~A}$ gene ( $h 2 A)$ (involved in normal cell cycle progression) may indicate two different cellular pathways, depending on the exposure concentration. The downregulation at LC hints on apoptotic processes, while the upregulation at $\mathrm{HC}$ exposure may imply cellular dysfunction occurring during necrotic processes, indicating a stronger negative effect of HC medium on Daphnia, that is in line with the higher mortality in this exposure. Activation of apoptotic pathways are positively correlated with the decline in $m$ hcrt (Tong et al., 2017) that was also observed in our study, suggesting apoptotic processes in $D$. magna, caused by cyanobacterial metabolites. Used concentrations of cyanobacterial metabolites in our exposures may have been too high for Daphnia to adapt, therefore use of lower concentration in future studies would provide deeper understading of Daphnia's molecular response to the cyanobacterial metabolites.

\section{CONCLUSION}

In conclusion, D. magna survival was strongly affected by cyanobacterial spent medium at both $\mathrm{LC}$ and $\mathrm{HC}$, due to the combined effect of MC and the other secondary metabolites present. D. magna were not able to acclimate during the short exposure period. Medium with the highest tested concentration of cyanobacterial metabolites was the most detrimental as expected. Exposure to cyanobacterial compounds in the $M$. aeruginosa spent medium affected D. magna genes involved in i) digestion, thus mobilization of the limited internal energetic resources, ii) oxidative stress and detoxification, iii) muscular activity and iv) cell regulation including the molting process. We also observed consequences of cyanobacterial medium on detoxification and antioxidant capacities which were dose and in particular time-

594 dependent indicating an exhaustion of the enzymes with high concentration or long exposure 595 duration. Despite this, the concentrations were chosen based on available data of pure MCs or MCs in crude extracts causing low lethality, for following sublethal effects an even lower concentration is recommended. 
601

602

603

604

605

606

607

608

609

610

611

612

613

614

615

616

617

618

619

620

621

622

623

624

625

626

627

628

629

630

631

632

633

634

635

636

637

638

639

Amado, L.L., Monserrat, J.M., 2010. Oxidative stress generation by microcystins in aquatic animals: Why and how. Environ. Int. doi:10.1016/j.envint.2009.10.010

Asselman, J., De Coninck, D.I.M., Glaholt, S., Colbourne, J.K., Janssen, C.R., Shaw, J.R., De Schamphelaere, K.A.C., 2012. Identification of pathways, gene networks, and paralogous gene families in daphnia pulex responding to exposure to the toxic cyanobacterium Microcystis aeruginosa. Environ. Sci. Technol. 46, 8448-8457. doi:10.1021/es301100j

Asselman, J., Hochmuth, J.D., De Schamphelaere, K.A.C., 2014. A comparison of the sensitivities of Daphnia magna and Daphnia pulex to six different cyanobacteria. Harmful Algae 39, 1-7. doi:10.1016/j.hal.2014.06.008

Barrios, C.A.Z., Nandini, S., Sarma, S.S.S., 2015. Effect of crude extracts of Dolichospermum planctonicum on the demography of Plationus patulus (Rotifera) and Ceriodaphnia cornuta (Cladocera). Ecotoxicology 24, 85-93. doi:10.1007/s10646-0141358-8

Beversdorf, L.J., Rude, K., Weirich, C.A., Bartlett, S.L., Seaman, M., Kozik, C., Biese, P., Gosz, T., Suha, M., Stempa, C., Shaw, C., Hedman, C., Piatt, J.J., Miller, T.R., 2018. Analysis of cyanobacterial metabolites in surface and raw drinking waters reveals more than microcystin. Water Res. 140, 280-290. doi:10.1016/j.watres.2018.04.032

Beversdorf, L.J., Weirich, C.A., Bartlett, S.L., Miller, T.R., 2017. Variable cyanobacterial toxin and metabolite profiles across six eutrophic lakes of differing physiochemical characteristics. Toxins (Basel). 9. doi:10.3390/toxins9020062

Bister, B., Keller, S., Baumann, H.I., Nicholson, G., Weist, S., Jung, G., Süssmuth, R.D., Jüttner, F., 2004. Cyanopeptolin 963A, a chymotrypsin inhibitor of Microcystis PCC 7806. J. Nat. Prod. 67, 1755-1757. doi:10.1021/np049828f

Bojadzija Savic, G., Bormans, M., Edwards, C., Lawton, L., Briand, E., Wiegand, C., 2020. Cross talk: Two way allelopathic interactions between toxic Microcystis and Daphnia. Harmful Algae 94, 101803. doi:10.1016/j.hal.2020.101803

Bojadzija Savic, G., Edwards, C., Briand, E., Lawton, L., Wiegand, C., Bormans, M., 2019. Daphnia magna Exudates Impact Physiological and Metabolic Changes in Microcystis aeruginosa. Toxins (Basel). 11, 421. doi:10.3390/toxins11070421

Bradford, M.M., 1976. A rapid and sensitive method for the quantitation of microgram quantities of protein utilizing the principle of protein-dye binding. Anal. Biochem. 72, 248-254. doi:10.1016/0003-2697(76)90527-3

Briand, E., Bormans, M., Gugger, M., Dorrestein, P.C., Gerwick, W.H., 2016. Changes in secondary metabolic profiles of Microcystis aeruginosa strains in response to intraspecific interactions. Environ. Microbiol. 18, 384-400. doi:10.1111/14622920.12904

Briand, E., Bormans, M., Quiblier, C., Salençon, M.J., Humbert, J.F., 2012. Evidence of the 

cost of the production of microcystins by Microcystis aeruginosa under differing light and nitrate environmental conditions. PLoS One 7, e29981. doi:10.1371/journal.pone.0029981

Calow, P., 1991. Physiological costs of combating chemical toxicants: ecological implications. Comp. Biochem. Physiol. C. 100, 3-6.

Chang, C.J., Kao, C.H., 1997. Plant growth regulation., Plant growth regulation. Kluwer Academic Publishers.

Chen, W., Song, L., Ou, D., Gan, N., 2005. Chronic toxicity and responses of several important enzymes in Daphnia magna on exposure to sublethal microcystin-LR, in: Environmental Toxicology. pp. 323-330. doi:10.1002/tox.20108

Colinet, H., Lee, S.F., Hoffmann, A., 2010. Temporal expression of heat shock genes during cold stress and recovery from chill coma in adult Drosophila melanogaster. FEBS J. 277, 174-185. doi:10.1111/j.1742-4658.2009.07470.x

Dao, T.S., Do-Hong, L.C., Wiegand, C., 2010. Chronic effects of cyanobacterial toxins on Daphnia magna and their offspring. Toxicon 55, 1244-1254. doi:10.1016/j.toxicon.2010.01.014

Dao, T.S., Ortiz-Rodríguez, R., Do-Hong, L.C., Wiegand, C., 2013. Non-microcystin and non-cylindrospermopsin producing cyanobacteria affect the biochemical responses and behavior of Daphnia magna. Int. Rev. Hydrobiol. 98, 235-244. doi:10.1002/iroh.201301626

De Coninck, D.I.M., Asselman, J., Glaholt, S., Janssen, C.R., Colbourne, J.K., Shaw, J.R., De Schamphelaere, K.A.C., 2014a. Genome-wide transcription profiles reveal genotype-dependent responses of biological pathways and gene-families in daphnia exposed to single and mixed stressors. Environ. Sci. Technol. 48, 3513-3522. doi:10.1021/es4053363

De Coninck, D.I.M., Asselman, J., Glaholt, S., Janssen, C.R., Colbourne, J.K., Shaw, J.R., De Schamphelaere, K.A.C., Pfrender, M.E., Lopez, J.A., De Coninck, D.I.M., Janssen, C.R., Shaw, J.R., De Schamphelaere, K.A.C., 2014b. Conserved transcriptional responses to cyanobacterial stressors are mediated by alternate regulation of paralogous genes in Daphnia. Mol. Ecol. 48, 1844-1855. doi:10.1021/es4053363

DeMott, W.R., 1999. Foraging strategies and growth inhibition in five daphnids feeding on mixtures of a toxic cyanobacterium and a green alga. Freshw. Biol. 42, 263-274. doi:10.1046/j.1365-2427.1999.444494.x

Demott, W.R., Zhang, Q.-X., Carmichael, W.W., 1991. Effects of toxic cyanobacteria and purified toxins on the survival and feeding of a copepod and three species of Daphnia. Limnol. Ocean. 36, 1346-357. doi:10.4319/1o.1991.36.7.1346

Drugă, B., Turko, P., Spaak, P., Pomati, F., 2016a. Cyanobacteria Affect Fitness and Genetic Structure of Experimental Daphnia Populations. Environ. Sci. Technol. 50, 3416-3424. doi:10.1021/acs.est.5b05973

Drugă, B., Turko, P., Spaak, P., Pomati, F., 2016b. Cyanobacteria Affect Fitness and Genetic Structure of Experimental Daphnia Populations. Environ. Sci. Technol. 50, 
682

683

684

685

686

687

688

689

690

691

692

693

694

695

696

697

698

699

700

701

702

703

704

705

706

707

708

709

710

711

712

713

714

715

716

717

718

719

720

721

Edwards, C., Lawton, L.A., Coyle, S.M., Ross, P., 1996. Laboratory-scale purification of microcystins using flash chromatography and reversed-phase high-performance liquid chromatography, in: Journal of Chromatography A. Elsevier B.V., pp. 163-173. doi:10.1016/0021-9673(95)01004-1

Elkobi-Peer, S., Singh, R.K., Mohapatra, T.M., Tiwari, S.P., Carmeli, S., 2013. Aeruginosins from a microcystis sp. bloom material collected in Varanasi, India. J. Nat. Prod. 76, 1187-1190. doi:10.1021/np4001152

Esterhuizen-Londt, M., von Schnehen, M., Kühn, S., Pflugmacher, S., 2016a. Oxidative stress responses in the animal model, Daphnia pulex exposed to a natural bloom extract versus artificial cyanotoxin mixtures. Aquat. Toxicol. 179, 151-157. doi:10.1016/j.aquatox.2016.09.003

Esterhuizen-Londt, M., von Schnehen, M., Kühn, S., Pflugmacher, S., Oxidative stress responses in the animal model, Daphnia pulex exposed to a natural bloom extract versus artificial cyanotoxin mixturesEsterhuizen-Londt, M., von Schnehen, M., Kühn, S., Pflugmacher, S., 2016b. Oxidative stress responses in the animal model, Daphnia pulex exposed to a natural bloom extract versus artificial cyanotoxin mixtures. Aquat. Toxicol. 179, 151-157. doi:10.1016/j.aquatox.2016.09.003

Ferrão-Filho, A.S., Herrera, N.A., Echeverri, L.F., 2014. Microcystin accumulation in cladocerans: First evidence of MC uptake from aqueous extracts of a natural bloom sample. Toxicon 87, 26-31. doi:10.1016/j.toxicon.2014.05.015

Fridovich, I., 1998. Oxygen toxicity: a radical explanation. J. Exp. Biol. 201.

Gademann, K., Portmann, C., 2008. Secondary Metabolites from Cyanobacteria: Complex Structures and Powerful Bioactivities. Curr. Org. Chem. 12, 326-341. doi:10.2174/138527208783743750

Gatte-Picchi, D., Weiz, A., Ishida, K., Hertweck, C., Dittmann, E., 2014. Functional analysis of environmental DNA-derived microviridins provides new insights into the diversity of the tricyclic peptide family. Appl. Environ. Microbiol. 80, 1380-1387. doi:10.1128/AEM.03502-13

Ger, K.A., Urrutia-Cordero, P., Frost, P.C., Hansson, L.A., Sarnelle, O., Wilson, A.E., Lürling, M., 2016. The interaction between cyanobacteria and zooplankton in a more eutrophic world. Harmful Algae 54, 128-144. doi:10.1016/j.hal.2015.12.005

Ghadouani, A., Pinel-Alloul, B., Plath, K., Codd, G. a., Lampert, W., 2004. Effects of Microcystis aeruginosa and purified microcystin-LR on the feeding behavior of Daphnia pulicaria. Limnol. Oceanogr. 49, 666-679. doi:10.4319/lo.2004.49.3.0666

Giraudo, M., Douville, M., Cottin, G., Houde, M., 2017. Transcriptomic, cellular and lifehistory responses of Daphnia magna chronically exposed to benzotriazoles: Endocrinedisrupting potential and molting effects. PLoS One 12, e0171763. doi:10.1371/journal.pone. 0171763

Gustafsson, S., Hansson, L.-A., 2004. Development of tolerance against toxic cyanobacteria in Daphnia. Aquat. Ecol. 38, 37-44. doi:10.1023/B:AECO.0000020985.47348.5e 
Hairston, N.G., Lampert, W., Cáceres, C.E., Holtmeier, C.L., Weider, L.J., Gaedke, U., Fischer, J.M., Fox, J. a., Post, D.M., 1999. Lake ecosystems: Rapid evolution revealed by dormant eggs. Nature 401, 446. doi:10.1038/46731

Hayes, J.D., Flanagan, J.U., Jowsey, I.R., 2005. Glutathione transferases. Annu. Rev. Pharmacol. Toxicol. 45, 51-88. doi:10.1146/annurev.pharmtox.45.120403.095857

Heisler, J., Glibert, P.M., Burkholder, J.M., Anderson, D.M., Cochlan, W., Dennison, W.C., Dortch, Q., Gobler, C.J., Heil, C.A., Humphries, E., Lewitus, A., Magnien, R., Marshall, H.G., Sellner, K., Stockwell, D.A., Stoecker, D.K., Suddleson, M., 2008. Eutrophication and harmful algal blooms: A scientific consensus. Harmful Algae 8, 313. doi:10.1016/j.hal.2008.08.006

Herrera, N.A., Echeverri, L.F., Ferrão-Filho, A.S., 2015. Effects of phytoplankton extracts containing the toxin microcystin-LR on the survival and reproduction of cladocerans. Toxicon 95, 38-45. doi:10.1016/j.toxicon.2014.12.016

Houde, M., Carter, B., Douville, M., 2013. Sublethal effects of the flame retardant intermediate hexachlorocyclopentadiene (HCCPD) on the gene transcription and protein activity of Daphnia magna. Aquat. Toxicol. 140-141, 213-219. doi:10.1016/j.aquatox.2013.06.008

Ighodaro, O.M., Akinloye, O.A., 2018. First line defence antioxidants-superoxide dismutase (SOD), catalase (CAT) and glutathione peroxidase (GPX): Their fundamental role in the entire antioxidant defence grid. Alexandria J. Med. 54, 287293. doi:10.1016/j.ajme.2017.09.001

Ishida, K., Christiansen, G., Yoshida, W.Y., Kurmayer, R., Welker, M., Valls, N., Bonjoch, J., Hertweck, C., Börner, T., Hemscheidt, T., Dittmann, E., 2007. Biosynthesis and Structure of Aeruginoside 126A and 126B, Cyanobacterial Peptide Glycosides Bearing a 2-Carboxy-6-Hydroxyoctahydroindole Moiety. Chem. Biol. 14, 565-576. doi:10.1016/j.chembiol.2007.04.006

Ishida, K., Nakagawa, H., Murakami, M., 2000. Microcyclamide, a cytotoxic cyclic hexapeptide from the cyanobacterium Microcystis aeruginosa. J. Nat. Prod. 63, 13151317. doi:10.1021/np000159p

Janssen, E.M.-L., 2019. Cyanobacterial peptides beyond microcystins - A review on cooccurrence, toxicity, and challenges for risk assessment. Water Res. 151, 488-499. doi:10.1016/J.WATRES.2018.12.048

Kaebernick, M., Rohrlack, T., Christoffersen, K., Neilan, B.A., 2001. A spontaneous mutant of microcystin biosynthesis: Genetic characterization and effect on Daphnia. Environ. Microbiol. 3, 669-679. doi:10.1046/j.1462-2920.2001.00241.x

Lahti, K., Rapala, J., Färdig, M., Niemelä, M., Sivonen, K., 1997. Persistence of cyanobacterial hepatotoxin, microcystin-LR in particulate material and dissolved in lake water. Water Res. 31, 1005-1012. doi:10.1016/S0043-1354(96)00353-3

Lanaras, T., Cook, C.M., 1994. Toxin extraction from an Anabaenopsis milleri dominated bloom. Sci. Total Environ. 142, 163-169. doi:10.1016/00489697(94)90324-7 
Liu, S., Ding, R., Nie, X., 2019. Assessment of oxidative stress of paracetamol to Daphnia magna via determination of $\mathrm{Nrf1}$ and genes related to antioxidant system. Aquat. Toxicol. 211, 73-80. doi:10.1016/j.aquatox.2019.03.014

Lürling, M., van der Grinten, E., 2003. Life-history characteristics of Daphnia exposed to dissolved microcystin-LR and to the cyanobacterium Microcystis aeruginosa with and without microcystins. Environ. Toxicol. Chem. 22, 1281-1287. doi:10.1002/etc.5620220614

Lyu, K., Gu, L., Li, B., Lu, Y., Wu, C., Guan, H., Yang, Z., 2016a. Stress-responsive expression of a glutathione S-transferase (delta) gene in waterflea Daphnia magna challenged by microcystin-producing and microcystin-free Microcystis aeruginosa. Harmful Algae 56, 1-8. doi:10.1016/j.hal.2016.04.009

Lyu, K., Guan, H., Wu, C., Wang, X., Wilson, A.E., Yang, Z., 2016b. Maternal consumption of non-toxic Microcystis by Daphnia magna induces tolerance to toxic Microcystis in offspring. Freshw. Biol. 61, 219-228. doi:10.1111/fwb.12695

Lyu, K., Wang, Q., Li, Z., Chen, R., Zhu, C., Liu, J., Yang, Z., 2014. Age-dependent survival and selected Gene expression in Daphnia magna after short-term exposure to low dissolved oxygen. J. Plankton Res. 37, 66-74. doi:10.1093/plankt/fbu097

MacKintosh, C., Beattie, K.A., Klumpp, S., Cohen, P., Codd, G.A., 1990. Cyanobacterial microcystin-LR is a potent and specific inhibitor of protein phosphatases 1 and $2 \mathrm{~A}$ from both mammals and higher plants. FEBS Lett. 264, 187-92.

Martin-Creuzburg, D., von Elert, E., Hoffmann, K.H., 2008. Nutritional constraints at the cyanobacteria-Daphnia magna interface: The role of sterols. Limnol. Oceanogr. 53, 456-468. doi:10.4319/lo.2008.53.2.0456

McKee, M.J., Knowles, C.O., 1986. Effects of fenvalerate on biochemical parameters, survival, and reproduction of Daphnia magna. Ecotoxicol. Environ. Saf. 12, 70-84. doi:10.1016/0147-6513(86)90007-2

Merwe, D. Van der, Sebbag, L., 2012. Investigation of a Microcystis aeruginosa cyanobacterial freshwater harmful algal bloom associated with acute microcystin toxicosis in a dog. J. Vet. ....

Miles, C.O., Sandvik, M., Nonga, H.E., Ballot, A., Wilkins, A.L., Rise, F., Jaabaek, J.A.H., Loader, J.I., 2016. Conjugation of Microcystins with Thiols Is Reversible: BaseCatalyzed Deconjugation for Chemical Analysis. Chem. Res. Toxicol. 29, 860-870. doi:10.1021/acs.chemrestox.6b00028

Mowe, M.A.D., Mitrovic, S.M., Lim, R.P., Furey, A., Yeo, D.C.J., 2015. Tropical cyanobacterial blooms: A review of prevalence, problem taxa, toxins and influencing environmental factors. J. Limnol. doi:10.4081/jlimnol.2014.1005

Natumi, R., Janssen, E.M.L., 2020. Cyanopeptide Co-Production Dynamics beyond Mirocystins and Effects of Growth Stages and Nutrient Availability. Environ. Sci. Technol. 54, 6063-6072. doi:10.1021/acs.est.9b07334

Neumann, U., Campos, V., Cantarero, S., Urrutia, H., Heinze, R., Weckesser, J., Erhard, M., 2000. Co-occurrence of non-toxic (cyanopeptolin) and toxic (microcystin) 

peptides in a bloom of Microcystis sp. from a Chilean lake. Syst. Appl. Microbiol. 23, 191-197. doi:10.1016/S0723-2020(00)80004-1

Ortiz-Rodríguez, R., Dao, T.S., Wiegand, C., 2012. Transgenerational effects of microcystin-LR on Daphnia magna. J. Exp. Biol. 215, 2795-2805. doi:10.1242/jeb.069211

Ortiz-Rodríguez, R., Wiegand, C., 2010. Age related acute effects of microcystin-LR on Daphnia magna biotransformation and oxidative stress. Toxicon 56, 1342-1349. doi:10.1016/j.toxicon.2010.07.020

Pane, E.F., McGeer, J.C., Wood, C.M., 2004. Effects of chronic waterborne nickel exposure on two successive generations of Daphnia magna. Environ. Toxicol. Chem. $23,1051-6$.

Pawlik-Skowrońska, B., Pirszel, J., Kornijów, R., 2008. Spatial and temporal variation in microcystin concentrations during perennial bloom of Planktothrix agardhii in a hypertrophic lake. Ann. Limnol. 44, 145-150. doi:10.1051/limn:2008015

Peng, S., Deng, D., He, P., Xu, X., Zhang, C., Cao, J., Liu, Q., Zhang, T., 2018. Effects of Microcystis aeruginosa on the life history traits and SOD activity of Daphnia similoides sinensis. Environ. Sci. Pollut. Res. 25, 30696-30707. doi:10.1007/s11356018-3040-9

Pfaffl, M.W., 2001. A new mathematical model for relative quantification in real-time RTPCR, Nucleic Acids Research.

Pflugmacher, S., Wiegand, C., Oberemm, A., Beattie, K.A., Krause, E., Codd, G.A., Steinberg, C.E.W.W., 1998. Identification of an enzymatically formed glutathione conjugate of the cyanobacterial hepatotoxin microcystin-LR: The first step of detoxication. Biochim. Biophys. Acta - Gen. Subj. 1425, 527-533. doi:10.1016/S0304-4165(98)00107-X

Pham, T.L., 2018. First report of microcystin-producing Microcystis (Chroococales, Cyanobacteria) in a central highland Vietnam lake. Fundam. Appl. Limnol. 191, 189197. doi:10.1127/fal/2018/1124

Portmann, C., Blom, J.F., Gademann, K., Jüttner, F., Jüttner, F., Jüttner, F., 2008. Aerucyclamides A and B: Isolation and synthesis of toxic ribosomal heterocyclic peptides from the cyanobacterium Microcystis aeruginosa PCC 7806. J. Nat. Prod. 71, 1193-1196. doi:10.1021/np800118g

Rastogi, R.P., Madamwar, D., Incharoensakdi, A., 2015. Bloom dynamics of cyanobacteria and their toxins: Environmental health impacts and mitigation strategies. Front. Microbiol. doi:10.3389/fmicb.2015.01254

Rhiannon, D.M., Dakic, V., Williams, T.D., Winter, M.J., Chipman, J.K., 2011. Transcriptional responses in neonate and adult Daphnia magna in relation to relative susceptibility to genotoxicants. Aquat. Toxicol. 104, 192-204. doi:10.1016/j.aquatox.2011.04.016

Rohrlack, T., Christoffersen, K., Kaebernick, M., Neilan, B.A., 2004. Cyanobacterial protease inhibitor microviridin J causes a lethal molting disruption in Daphnia 

pulicaria. Appl. Environ. Microbiol. 70, 5047-5050. doi:10.1128/AEM.70.8.50475050.2004

Rohrlack, T., Dittmann, E., Börner, T., Christoffersen, K., 2001. Effects of Cell-Bound Microcystins on Survival and Feeding of Daphnia spp. Appl. Environ. Microbiol. 67, 3523-3529. doi:10.1128/AEM.67.8.3523-3529.2001

Sadler, T., von Elert, E., 2014a. Physiological interaction of Daphnia and Microcystis with regard to cyanobacterial secondary metabolites. Aquat. Toxicol. 156, 96-105. doi:10.1016/j.aquatox.2014.08.003

Sadler, T., von Elert, E., 2014b. Dietary exposure of Daphnia to microcystins: No in vivo relevance of biotransformation. Aquat. Toxicol. 150, 73-82. doi:10.1016/j.aquatox.2014.02.017

Sarnelle, O., Wilson, A.E., 2005. Local adaptation of Daphnia pulicaria to toxic cyanobacteria. Limnol. Oceanogr. 50, 1565-1570. doi:10.4319/lo.2005.50.5.1565

Schwarzenberger, A., Courts, C., von Elert, E., 2009. Target gene approaches: Gene expression in Daphnia magna exposed to predator-borne kairomones or to microcystin-producing and microcystin-free Microcystis aeruginosa. BMC Genomics 10, 527. doi:10.1186/1471-2164-10-527

Schwarzenberger, A., Kuster, C.J., Von Elert, E., 2012. Molecular mechanisms of tolerance to cyanobacterial protease inhibitors revealed by clonal differences in Daphnia magna. Mol. Ecol. 21, 4898-4911. doi:10.1111/j.1365-294X.2012.05753.x

Schwarzenberger, A., Zitt, A., Kroth, P., Mueller, S., Von Elert, E., 2010. Gene expression and activity of digestive proteases in Daphnia: Effects of cyanobacterial protease inhibitors. BMC Physiol. 10, 6. doi:10.1186/1472-6793-10-6

Smutná, M., Babica, P., Jarque, S., Hilscherová, K., Maršálek, B., Haeba, M., Bláha, L., 2014. Acute, chronic and reproductive toxicity of complex cyanobacterial blooms in Daphnia magna and the role of microcystins. Toxicon 79. doi:10.1016/j.toxicon.2013.12.009

Street, S.M., Eytcheson, S.A., LeBlanc, G.A., 2019. The role of nuclear receptor E75 in regulating the molt cycle of Daphnia magna and consequences of its disruption. PLoS One 14, e0221642. doi:10.1371/journal.pone.0221642

Su, X., Xue, Q., Steinman, A.D., Zhao, Y., Xie, L., 2015. Spatiotemporal dynamics of microcystin variants and relationships with environmental parameters in lake Taihu, China. Toxins (Basel). 7, 3224-3244. doi:10.3390/toxins 7083224

Svirčev, Z., Lalić, D., Bojadžija Savić, G., Tokodi, N., Drobac Backović, D., Chen, L., Meriluoto, J., Codd, G.A., 2019. Global geographical and historical overview of cyanotoxin distribution and cyanobacterial poisonings. Arch. Toxicol. 1-53. doi:10.1007/s00204-019-02524-4

Tong, Q., Zhang, M., Cao, X., Xu, S., Wang, D., Zhao, Y., 2017. Expression and activation of Daphnia pulex Caspase-3 are involved in regulation of aging. Gene 634, 37-46. doi:10.1016/j.gene.2017.08.035

Trinkle-Mulcahy, L., Lamond, A.I., 2006. Mitotic phosphatases: no longer silent partners. 
Von Elert, E., Agrawal, M.K., Gebauer, C., Jaensch, H., Bauer, U., Zitt, A., 2004. Protease activity in gut of Daphnia magna: Evidence for trypsin and chymotrypsin enzymes. Comp. Biochem. Physiol. - B Biochem. Mol. Biol. 137, 287-296. doi:10.1016/j.cbpc.2003.11.008

Von Elert, E., Oberer, L., Merkel, P., Huhn, T., Blom, J.F., 2005. Cyanopeptolin 954, a 895 chlorine-containing chymotrypsin inhibitor of Microcystis aeruginosa NIVA Cya 43. J. Nat. Prod. 68, 1324-1327. doi:10.1021/np050079r

von Elert, E., Zitt, A., Schwarzenberger, A., 2012. Inducible tolerance to dietary protease inhibitors in Daphnia magna. J. Exp. Biol. 215, 2051-2059. doi:10.1242/jeb.068742

von Elert, Eric, Zitt, A., Schwarzenberger, A., 2012. Inducible tolerance to dietary protease inhibitors in Daphnia magna. J. Exp. Biol. 215, 2051-2059. doi:10.1242/jeb.068742

Wang, L., Peng, Y., Nie, X., Pan, B., Ku, P., Bao, S., 2016. Gene response of CYP360A, CYP314, and GST and whole-organism changes in Daphnia magna exposed to ibuprofen. Comp. Biochem. Physiol. Part - C Toxicol. Pharmacol. 179, 49-56. doi:10.1016/j.cbpc.2015.08.010

Welker, M., Von Döhren, H., 2006. Cyanobacterial peptides - Nature's own combinatorial biosynthesis. FEMS Microbiol. Rev. doi:10.1111/j.1574-6976.2006.00022.x

Wiegand, C., Peuthert, A., Pflugmacher, S., Carmeli, S., 2002. Effects of microcin SF608 and microcystin-LR two cyanotobacterial compounds produced by Microcystis sp., on aquatic organisms. Environ. Toxicol. 17, 400-406. doi:10.1002/tox.10065

Wiegand, C., Pflugmacher, S., Oberemm, A., Steinberg, C., 2000. Activity development of selected detoxication enzymes during the ontogenesis of the zebrafish (Danio rerio). Int. Rev. Hydrobiol. 85, 413-422. doi:10.1002/1522-2632(200008)85:4<413::AIDIROH413>3.0.CO;2-3

Wojtal-Frankiewicz, A., Bernasi??ska, J., Jurczak, T., Gwo??dzi??ski, K., Frankiewicz, P., Wielanek, M., 2013. Microcystin assimilation and detoxification by Daphnia spp. in two ecosystems of different cyanotoxin concentrations. J. Limnol. 72, 154-171. doi:10.4081/jlimnol.2013.e13

Wojtal-Frankiewicz, A., Bernasińska, J., Frankiewicz, P., Gwoździński, K., Jurczak, T., 2014. Response of daphnia's antioxidant system to spatial heterogeneity in cyanobacteria concentrations in a lowland reservoir. PLoS One. doi:10.1371/journal.pone.0112597

Ziemert, N., Ishida, K., Weiz, A., Hertweck, C., Dittmann, E., 2010. Exploiting the natural diversity of microviridin gene clusters for discovery of novel tricyclic depsipeptides. Appl. Environ. Microbiol. 76, 3568-3574. doi:10.1128/AEM.02858-09

Zurawell, R.W., Chen, H., Burke, J.M., Prepas, E.E., 2005. Hepatotoxic cyanobacteria: a review of the biological importance of microcystins in freshwater environments. J. Toxicol. Environ. Health. B. Crit. Rev. 8, 1-37. doi:10.1080/10937400590889412 